\title{
Acute Kidney Injury in Heroin Users
}

\author{
Ileana Adela VACAROIU ${ }^{1,2}$, Daniela RADULESCU ${ }^{1,2}$, Anca loana STANESCU²
}

\begin{abstract}
The article presents a case of severe necrotizing fasciitis and rhabdomyolysis-induced acute tubular necrosis resulting from the injection of heroin laced with a plant-fertilizer known as "Pure by Magic". We also review the literature data regarding the renal adverse effects of heroin. Due to the diversity of adulterants used by drug dealers for cutting heroin and the variety of substances patients mix the heroin with before injecting themselves, the effects of this practice are often unknown and the treatment lacks of antidote, being strictly symptomatic.
\end{abstract}

Keywords: heroin addiction, laced heroin, ethnobotanicals, acute kidney injury, necrotizing fasciitis.

\section{Rezumat}

Articolul prezintă cazul unui pacient dependent de heroină care a dezvoltat o formă severă de fasceită necrozantă şi necroză tubulară acută prin rabdomioliză după injectarea de heroină amestecată cu un fertilizator vândut pe piața neagră sub denumirea de „Pure by Magic". Din cauza diversității aditivilor folosiți de traficanții de droguri pentru „tăierea" heroinei și a varietății de substanțe cu care pacienții amestecă heroina înainte de a se injecta, efectele acestei practici sunt adesea necunoscute, iar tratamentul este lipsit de antidot, fiind strict simptomatic.

Cuvinte cheie: dependență de heroină, heroina „tăiată”, etnobotanice, injurie acută a rinichiului, fasceită necrozantă.

\section{INTRODUCTION}

Drug abuse is on the rise worldwide. Reports from United Nations Office on Drugs and Crime (UNODC) highlight that in 2019, compared to 2009, there was a $30 \%$ increase in the number of individuals who use drugs ${ }^{1}$. Among these drugs, heroin use is placed on the second place after cannabis; 2020 UNODC report shows a prevalence of opiate use of $1.2 \%$ of the population, or 57.8 million people ${ }^{2}$. In Romania, the National Anti-Drug Agency estimated a number of 20.288 opiate users in 2017: $95.6 \%$ were heroin users, ie $0.3 \%$ of the population. As a route of administration, heroin ranks first among injecting drugs, occurring in $89.2 \%$ of people who abuse drugs ${ }^{3}$.

Street heroin, as other illegal drugs, is often „cut” with different substances by drug-dealers, such as baking soda, talcum powder, powdered milk, laundry

${ }^{1}$ Clinical Department no.3, "Carol Davila"University of Medicine and Pharmacy, Bucharest, Romania

${ }^{2}$ Clinic of Nephrology and Dialysis, „Sf. Ioan"Emergency Clinical

Hospital, Bucharest, Romania detergent, rat poison, starch, sugar, fentanyl, paracetamol or warfarin ${ }^{4}$. Nevertheless, it has become popular among drug users to lace already "cut heroin" with other substances in order to enhance its psycho-stimulant effects. Among these, there are reports stating that the new psychoactive drugs, also known as ethnobotanics, are the most preferred in Romania ${ }^{5,6}$. Although the so called „weed shops” are illegal in Romania since $2011^{7}$, presently there is not only a persistent use among young people, but also proofs of diversification of such substances ${ }^{5,6}$. Unfortunately, the exact composition of many psychoactive drugs sold in the street or on the internet is not entirely known; therefore the adverse effects of their use are incompletely described.

We present the case of a heroin-addicted patient who developed a severe reaction after injection of heroin laced with a substance known by the name of „Pure by Magic”.

\section{Corresponding author.}

Daniela RADULESCU, Clinic of Nephrology and Dialysis,

„Sf. Ioan"Emergency Clinical Hospital, 13 Vitan-Barzesti Avenue,

Bucharest, 042122, Romania.

E-mail: danielaradulescu64@yahoo.com 


\section{CASE PRESENTATION}

History and clinical exam. A 40-year-old male presented to our emergency department for oligoanuria, edema and purpuric lesions of the lower right limb and cyanosis of the right sole (Figure 1). He admitted to be an intravenous heroin drug user since the age of 30 , currently in a methadone substitution therapy programme. He reported that in the last 6 months he started buying heroin from his drug dealer again and has been using heroin daily ever since. 4 days ago, he mixed the heroin with a powder called „Pure by Magic", dissolved it in tap water and injected a volume of approximately $7-8 \mathrm{~mL}$ in his right inguinal region. Initially, he noticed some small reddish spots on his lower right limb, then edema of the entire limb occurred and rapidly aggravated. No other local or systemic symptoms were present, except a reduction of the urine output in the last 48 hours.

From his personal history we noted that he was diagnosed with chronic hepatitis $\mathrm{C}$ for which he received treatment with interferon for 6 months. $\mathrm{He}$ was currently under chronic daily medication with Methadone $70 \mathrm{mg}$, Alprazolam $2 \mathrm{mg}$ and Quetiapine $150 \mathrm{mg}$. He was an active smoker.
On local examination, it was noted that his lower right limb was almost entirely covered by purpuric lesions, with cyanosis of the right limb and sole (Figure 1). The limb was warm, with abnormal bulk and tone. Pain reflexes were abolished, but pulse was present in all sites of the lower limb. General physical examination also revealed high blood pressure $(160 / 100 \mathrm{mmHg})$ and hepatosplenomegaly, but no other abnormalities. A urinary catheterization was performed and $500 \mathrm{~mL}$ of hypercromic urine were evacuated.

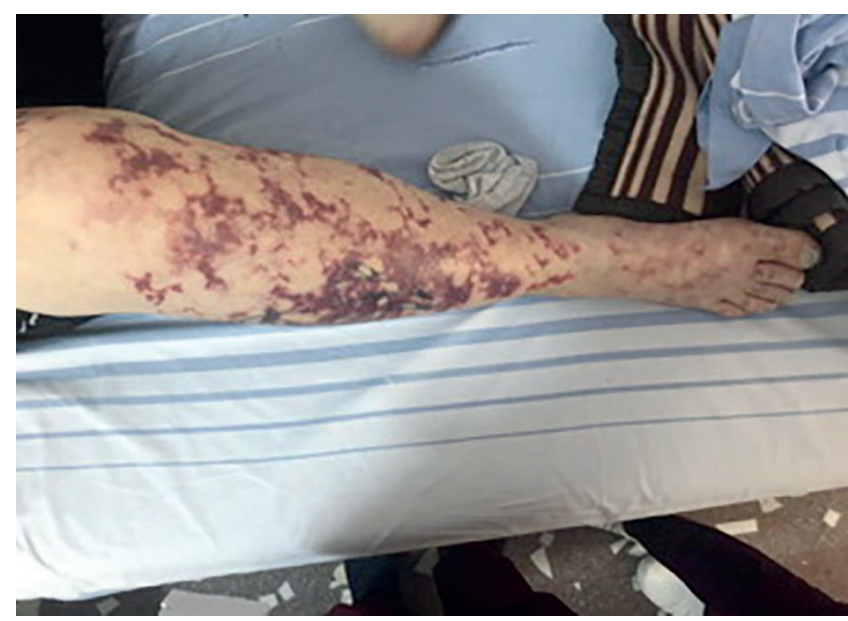

Figure 1. Purpuric lesions and cyanosis on the patient's right lower limb

Table 1. Abnormal blood analysis

\begin{tabular}{|c|c|c|c|c|c|}
\hline Blood analysis & RESULTS & Blood analysis & RESULTS & Blood analysis & RESULTS \\
\hline White blood cells & $12,000 / \mu \mathrm{L}$ & TGO & $1235.4 \mathrm{IUL} / \mathrm{L}$ & Phosphorus & $7.32 \mathrm{md} / \mathrm{dL}$ \\
\hline Neutrophils & $9,000 / \mu \mathrm{L}$ & TGP & $760.4 \mathrm{IU} / \mathrm{L}$ & Corrected Ca & $7.15 \mathrm{mg} / \mathrm{dL}$ \\
\hline Platelets & $175,000 / \mu \mathrm{L}$ & LDH & $2645 \mathrm{IU} / \mathrm{L}$ & Sodium & $130 \mathrm{mE} \mathrm{q} / \mathrm{L}$ \\
\hline Urea & $195.3 \mathrm{mg} / \mathrm{dL}$ & $\mathbf{C K}$ & $131,700 \mathrm{IU} / \mathrm{L}$ & Potassium & $5.9 \mathrm{mE} / \mathrm{L}$ \\
\hline Creatinine & $12.14 \mathrm{mg} / \mathrm{dL}$ & CK-MB & $1552 \mathrm{IU} / \mathrm{L}$ & Bicarbonate & $18 \mathrm{mmo} / \mathrm{L}$ \\
\hline Uric acid & $13.2 \mathrm{mg} / \mathrm{dL}$ & NT proBNP & $520 \mathrm{pg} / \mathrm{mL}$ & Anionic gap & $25.8 \mathrm{mEq} / \mathrm{L}$ \\
\hline Cholesterol & $257 \mathrm{mg} / \mathrm{dL}$ & hsTnI & $406 \mathrm{ng} / \mathrm{mL}$ & ESR & $84 \mathrm{~mm} / 1 \mathrm{~h}$ \\
\hline Triglycerides & $198 \mathrm{mg} / \mathrm{dL}$ & Albumin & $2.8 \mathrm{~g} / \mathrm{dL}$ & HsCRP & $25.5 \mathrm{mg} / \mathrm{dL}$ \\
\hline
\end{tabular}

Blood and urine work-up. As highlighted in table I, characteristic features of rhabdomyolysis syndrome were present associated with severe increased nitrogenous waste products and altered serum electrolytes and inflammatory markers. Beside these, the following were noted: increased serum Ig E (586 IU/L), positive test for hepatitis $\mathrm{C}$ antibodies, negative tests for hepatitis $B$ and HIV markers. Serum cryoglobulines tested negative and the serum levels of the fractions of the complement as well as the IgM and IgG levels were all within normal range. Clotting tests were unaltered. 
The urinalysis showed specific gravity of 1010 and a $\mathrm{pH}$ of 6.5 , with marked hematuria, proteinuria and leukocyturia, with a sediment examination in light microscopy with rare leukocytes and isomorphic erythrocytes. Urine cultures were positive for coagulasenegative staphylococci. Urine drug screen was positive for methadone, opioids, cannabinoids and tricyclic antidepressants. 24-hour proteins were quantified and a result of $856 \mathrm{mg} /$ day was obtained, from which albumin was $125 \mathrm{mg}$.

Imaging. Except for a slightly prolonged corrected QT interval (476 ms), probably due to methadone use in the presence of concomitant severe kidney dysfunction ${ }^{8}$, no abnormalities were found on the electrocardiogram. On the admission, chest radiograph and kidney ultrasound were normal (Figure 2). Doppler ultrasonography ruled out both arterial obstruction and venous thrombosis.
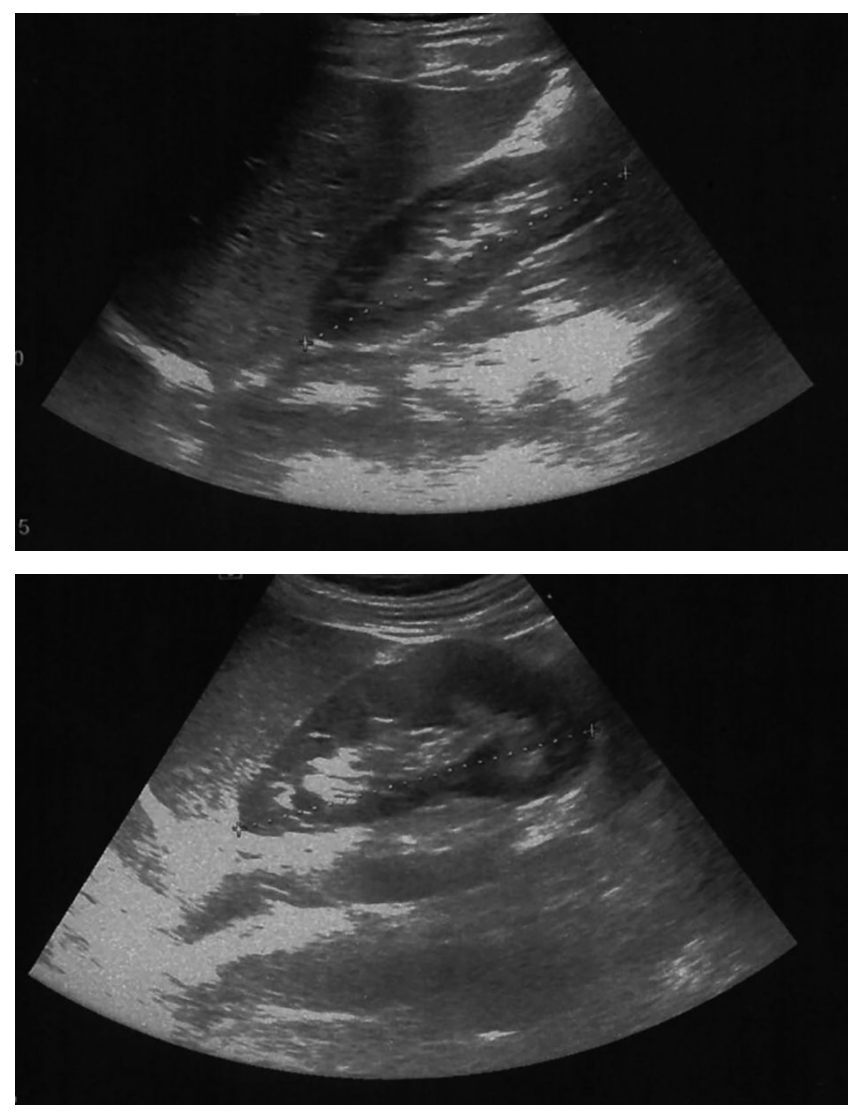

Figure 2. Ultrasound showing normal-sized kidneys
In-hospital evolution. After a brief period of conservative treatment, hemodialysis was initiated along with antibiotherapy. Concomitantly, necrotizing fasciitis was diagnosed and the patient underwent fasciotomies in the plastic surgery department. Massive muscular destruction was found intraoperatively and required no less than 3 surgical interventions with general anesthesia. The pathogen isolated from the lower limb tissue culture was Enterococcus spp and the patient received antimicrobial therapy according to the sensitivity results. After a total period of 3 weeks, the patient regained full function of the lower limb. Diuresis also resumed in parallel with regression of serum and urine abnormalities, therefore, after 9 sessions, hemodialysis was stopped. At the moment of discharge, the patient had a creatinine level of $2.3 \mathrm{mg} /$ $\mathrm{dL}$, and after 3 months it was in normal range.

\section{DISCUSSIONS AND REVIEW OF LITERATURE}

Heroin abuse is associated with several renal adverse effects, but it is difficult to separate the effects of heroin per se from those induced by heroin adulterants or by the frequently associated diseases (chronic hepatitis, infectious endocarditis, HIV infection $)^{9-11}$. Most of the authors, reviewing the literature reports, stipulate that nowadays we cannot identify specific effects of pure heroin on the kidney structure and function and most adverse reactions are secondary to the above-stipulated factors ${ }^{10}$.

Thus, the classically so called „heroin nephropathy”, meaning focal segmental glomerulosclerosis, is usually secondary to HIV infection, being more frequently encounteredinAfro-Americans.Membranoproliferative glomerulonephritis and cryoglobulinemic glomerular disease - recorded especially in Caucasian heroinusers - are frequently associated with chronic hepatitis or infective endocarditis ${ }^{9,10,12}$. Also, renal amydoidosis seems to be related to chronic inflammation and/or infection in intravenous heroin-users ${ }^{13,14}$. No features of nephritic or nephrotic syndrome were present in our patient.

Acute kidney injury from interstitial nephritis is also cited in the literature, usually an acute allergic form secondary to the adulterants of heroin ${ }^{9,10}$; in the presented case, increased Ig E was present, although no abnormal eosinophil levels were noted. Also, urine abnormalities presented characteristics of tubular 
dysfunction. Therefore this scenario was possible, but we had no data regarding the adulterants of heroin he injected.

Beside acute allergic tubulointerstitial nephritis, acute kidney injury in heroin chronic users may be secondary to tubular obstruction with heroin crystals ${ }^{15}$, but there was no specification of crystals in the urine sediment in our patient.

Our case is a clear rhabdomyolysis-induced acute tubular necrosis additionally aggravated by the compartment syndrome and the associated infection. Nevertheless, heroin-induced rhabdomyolysis has been, in comparison with cocaine, rarely reported in the literature, and only in cases of heroin overdose ${ }^{16-18}$. The patient we present had no signs of acute heroin intoxication $^{19}$, i.e. he was conscious, had normal respiratory rhythm, had no hypotension, bradycardia or miosis. Moreover, he did not change the drug dealer, nor his daily dose of heroin.

Therefore, we concluded that the mainly responsible for rhabdomyolysis in the case presented was the „Pure by Magic" powder. There are some reports of increased consume of ethnobotanical substances having names derived from „Magic” (Flower Magic, White Magic) among Romanian drug users ${ }^{6,20}$; most of them contain mephredone, a synthetic drugs from cathinones class with stimulating effects similar to those of cocaine and having well-described side effects ${ }^{21}$. However, despite the partial similarity of the name, „Pure by Magic” does not contain mephedrone. „Pure by Magic” is a powder commonly used for fertilizing Salix Fragilisis (Crack-Willow), as various internet sources stipulate.
It is a particularly dangerous substance for human use because there is no official laboratory evidence of the active substances, and its consumption sometimes leads to severe hallucinations, additional to the cocainelike effects ${ }^{6}$. Some empirical assessments indicate similarities to Naphyrone $e^{6,20}$, a pyrovalerone derivate which, consumed by sniffing, provokes dependence, psychosis and overstimulation of cardiovascular system ${ }^{22}$. In our patient, there was an important increase of high-sensitive troponin I, and also of NT-proBNP, and these abnormalities may also be explained by the use of fertilizer. We found no reports available in the literature regarding the adverse effects of injected „Pure by Magic".

\section{CONCLUSIONS}

Patients exposed to illicit drugs are at high risk of developing life-threatening complications. Diversification of drug offers on the black market and incomplete data regarding their chemical structure pose the physicians in the situation of acting empirically, meaning applying only symptomatic treatment. Luckily for the patient presented in the article, treatment was successful and permitted full recovery.

Compliance with ethics requirements: The authors declare no conflict of interest regarding this article. The authors declare that all the procedures and experiments of this study respect the ethical standards in the Helsinki Declaration of 1975, as revised in 2008(5), as well as the national law. Informed consent was obtained from all the patients included in the study. 


\section{References}

1. United Nations Office on Drugs and Crime. World Drug Report 2019. Available at: https://www.unodc.org/unodc/ en/frontpage/2019/June/world-drug-report-2019, accessed February 2021.

2. United Nations Office on Drugs and Crime. World Drug Report 2020. Available at https://wdr.unodc.org/wdr2020/index.html, accesses February 2021.

3. Agentia Nationala Antidrog. Raport național privind situația drogurilor. 2019. Noi evoluții şi tendințe. Accesibil la: http:// ana.gov.ro/wp-content/uploads/2020/01/RN_2019_28.11.pdf, accessed February 2021.

4. Marisa Crane BS. What Is Heroin Cut With? Available at: https:// americanaddictioncenters.org/heroin-treatment/cut-with?, accessed February 2021.

5. Corlade-Andrei M, Cimpoeşu D, Butnaru E. Issues on the Use of Ethnobotanicals/Aspecte privind consumul de produse etnobotanice. Rev Med Chir Soc Med Nat, Iaşi, 2011; 115(4): 1069-1072.

6. Botescu A. Evaluarea riscurilor asociate consumului de substanțe noi cu proprietăți psihoactive. Editura ALPHA MDN, Bucureşti, 2011. ISBN 978-973-139-196-0

7. Legea nr. 194 din 7 noiembrie 2011 privind combaterea opera iunilor cu produse susceptibile de a avea efecte psihoactive, altele decât cele prevăzute de acte normative în vigoare. Monitorul Oficial nr. 140, 2014.

8. Chou R, Cruciani RA, Fiellin DA, Compton P, Farrar JT, Haigney MC, Inturrisi C, Knight JR, Otis-Green S, Marcus SM, Mehta D, Meyer MC, Portenoy R, Savage S, Strain E, Walsh S, Zeltzer L; American Pain Society; Heart Rhythm Society. Methadone safety: a clinical practice guideline from the American Pain Society and College on Problems of Drug Dependence, in collaboration with the Heart Rhythm Society. J Pain. 2014;15(4): 321-337.

9. Sethi S. The Changing Spectrum of Heroin-Associated Kidney Disease. CJASN. 2018; 13(7): 975-976

10. Jaffe JA, Kimmel PL. Chronic nephropathies of cocaine and heroin abuse: a critical review. Clin J Am Soc Nephrol. 2006; 1(4):655-667.

11. do Sameiro Faria M, Sampaio S, Faria V, Carvalho E. Nephropathy associated with heroin abuse in Caucasian patients. Nephrol Dial Transplant. 2003; 18(11): 2308-2313.
12. Sethi S, Fervenza FC. Membranoproliferative glomerulonephritis-a new look at an old entity. N Engl J Med. 2012; 366(12): 11191131.

13. Menchel S, Cohen D, Gross E, Frangione B, Gallo G. AA proteinrelated renal amyloidosis in drug addicts. Am J Pathol. 1983; 112(2): 195-199.

14. Sharma A, Govindan P, Toukatly M, Healy J, Henry C, Senter S, Najafian B, Kestenbaum B. Heroin Use Is Associated with AAType Kidney Amyloidosis in the Pacific Northwest. Clin J Am Soc Nephrol. 2018; 13(7): 1030-1036.

15. Bautista JE, Merhi B, Gregory O, Hu S, Henriksen K, Gohh R. Heroin crystal nephropathy. Clin Kidney J. 2015; 8(3): 339-342.

16. Otero A, Esteban J, Martinez J, Cejudo C. Rhabdomyolysis and acute renal failure as a consequence of heroin inhalation. Nephron. 1992; 62(2):245..

17. Wan SH, Szeto ML. Rhabdomyolysis and heroin addiction. Hong Kong Med J. 1995; 1: 266-268.

18. Madhusoodanan S, Gupta S, Calleja G, Bogunovic O, Brenner R. A Case of Rhabdomyolysis After Intravenous Heroin Use. Prim Care Companion J Clin Psychiatry. 2004; 6(5): 221-222.

19. Habal R. Heroin Toxicity Clinical Presentation. Medscape 2020. Available at: https://emedicine.medscape.com/article/166464clinical\#b4, accessed February 2021.

20. Ghionea (Moraru) M. Implica ii medico-legale ale consumului de substan e psihoactive la copii și tineri/Medico-legal implication of psychoactive substance use among youth. Abstract thesis. Available at: https://umfcd.ro/wp-content/uploads/2017/09/ SUSTINERE_TEZA/GHEONEA_CAS_MORARU_N_MONICA/Teza_ rezumat-.pdf, accessed March 2021.

21. Wood DM, Dargan PI. Chapter 9 - Mephedrone. In: Wood DM, Dargan PI (editors). Novel Psychoactive Substances: Classification, Pharmacology and Toxicology. Academic Press. 2013; Pages: 211-231.

22. Vardakou I, Pistos C, Dona A, Spiliopoulou C, Athanaselis S. Naphyrone: a "legal high" not legal any more. Drug Chem Toxicol. 2012; 35(4): 467-471. 